\title{
Vessel guardians: sculpture and graphics related to the ceramics of North-Eastern European hunter-gatherers
}

\author{
Ekaterina Kashina, ${ }^{1}$ Aleksandr Zhulnikov 2 \\ 1 State Historical Museum, Department of Archaeology, Moscow, RU \\ eakashina@mail.ru \\ 2 Petrozavodsk State University, Chair of History, Petrozavodsk, Republic of Karelia, RU \\ rockart@yandex.ru
}

\begin{abstract}
North-Eastern European hunter-gatherer ceramic sculptures, relief sculptures and graphic images on vessels are discussed. Five groups of finds are distinguished according to their chronology (4000-2500 calBC) and the subject that is represented (birds, human heads, human figures, mammal heads etc.). We believe that the production of these items was a female craft; they were made for ritual purposes and their emergence was independent of any influence from pastoral/agricultural societies.
\end{abstract}

IZVLEČEK - V članku predstavljamo skulpture, reliefe in grafične upodobitve na keramičnih posodah lovcev in nabiralcev v severnovzhodni Evropi. Glede na kronologijo (4000-2500 calBC) in upodobitve (ptice, človeške glave, človeške figure, glave sesalcev itd.) ločimo pet skupin najdb. Posode so izdelovale ženske; namenjene so bile ritualni uporabi in niso povezane z vplivi živinorejsko-poljedelskih skupnosti.

KEY WORDS - hunter-gatherers; forest zone; Eastern Europe; ceramics; clay sculpture

\section{Introduction}

It is well known today that north Eurasian Holocene hunter-gatherer-fishing peoples used ceramic vessels, but it is less known that they also made small clay sculptures, depicting human, zoomorphic and probably mixed/fantastic images. Moreover, there existed clay sculptures merged with vessels have been found, which parallel numerous and well-known finds from south-east European and Near Eastern agricultural societies. Graphic images of birds and humans on ceramics are also known among northeast European foragers. The making of clay sculpture survived among forest zone foragers for an extremely long time, until the Early Iron Age, the first centuries $\mathrm{AD}$, when agriculture finally became a constant (and sometimes considerable) element of subsistence.
This paper focuses on artefacts from the period from 4000 to 2500 calBC (in Russian archaeological literature, traditionally defined as the Middle/Late Neolithic - Eneolithic/Early Metal Period). ${ }^{1}$ A number of cultures of presumably sedentary groups engaged in hunting, gathering and fishing were dispersed over a huge area of the north-east European forest zone, including modern Russia (to the west of the Urals), the eastern Baltic countries and partly Finland (see Fig. 1).

Most of the settlements in these regions are as multilayer sites, where mixed artefacts from different epochs, usually from the Late Mesolithic to the Neolithic, Bronze, sometimes even the Iron Age, can be identified. The landscape of the Russian Plain is full

1 The Early Metal Period is the term applied to the period of transition from the Neolithic to the Bronze and Early Iron Age in the north-eastern European forest zone (e.g., in Finland, North Karelia and the Arkhangelsk districts of Russia), where the presence of metal items occured extremely late in comparison with other parts of the forest zone; therefore, the terms 'Eneolithic' and 'Bronze Age' are not used there. 
of rivers; the main basins are formed by huge rivers, such as the Volga, Western Dvina, Northern Dvina and their numerous tributaries, large and small, and lakes, which together form a wide network of waterways. Most of this area could have been used all year round, by boat in warmer seasons and on ice in winter. Fishing played a considerable (if not the leading) part in subsistence, which is argued in numerous studies on technology and paleo-dietary matters (see e.g., Piezonka et al. 2013). The most common type of dwelling at that time was semi-subterranean and rectangular, with fireplace(s) inside, narrow inclined exit(s), wooden plank walls, and measuring $40-120 \mathrm{~m}^{2}$. Ceramics appeared around 5500-5000 calBC (that is, the beginning of the Neoli-

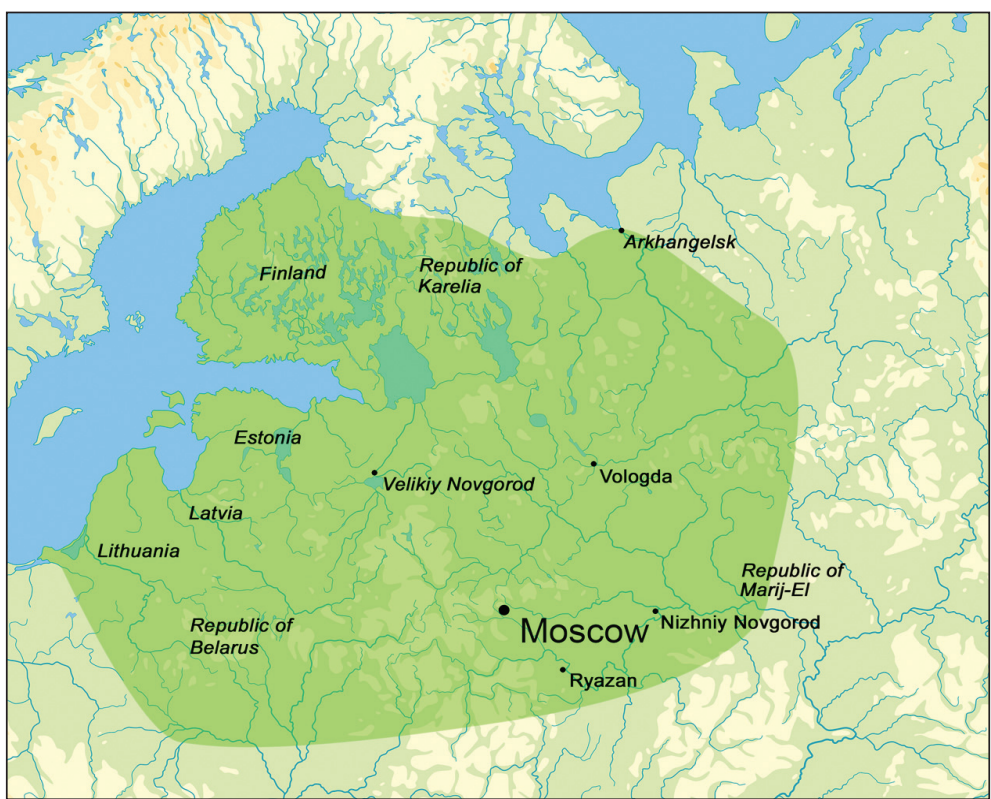

Fig.1. Zone of distribution of portable ceramic art in north-eastern Europe (map: E. Kashina). thic for Eurasian forest zone foragers) and its development during the next 2500 years, stated briefly, go through several great phases: 'Early Neolithic' (plain surface, poor decoration, 5500-4000 calBC), 'Middle Neolithic' (mineral temper, comb and pit decoration, 4000-3000 calBC), 'Late Neolithic' and 'Early Bronze' or 'Early Metal Period' (different organic temper - so-called Porous Ware - comb and pit decoration of numerous types, 3000-2500 calBC and later) (Oshibkina 1996; Bahder et al. 1987). Obviously, the process of adopting ceramic technology was faster in southern parts of the north European forest zone, while the northern part seems to have been rather 'conservative' and even 'slow' in the uptake of ceramic technology.

The making of Stone Age hunter-gatherer ceramics is believed to have been a female domain. The considerably fast spread of ceramic technologies to the north appears to have been connected with kinship alliances (Tsetlin 1998; Zhulnikov 2006). Due to climate conditions, pots could only be made in the summer. Vessels of simple oval - or egg-shaped forms with a diameter of 20 to $40 \mathrm{~cm}$ were probably used for storage as well; organic cooking residue occurs considerably rarely; some sherds have holes indicating attempts to repair broken vessels; some vessels were buried.

Clay sculpture in the Eastern European forest zone appear in the form of sets, which are widespread among cultures with Comb-Pitted Ware of the Eastern Baltic basin, and located beside the hearth in dwellings. They comprise several human figures (schematic, embryo-like) (Kashina 2009), birds, snakes and mammals - elk, beaver, or otter. Some were painted with red ochre; others could have been placed on a flat surface, because have flat bases or holes in the bottom for a thin handle to be attached (Kashina 2007). Most of the items were found in fragments, but there is no evidence that clay sculptures were deliberately destroyed, although some researchers have expressed this opinion (Nuñez 1986; Loze 2005). The most probable reason for the fragmentation is the multi-layered character of the sites and the occasional nature of the particular domestic rituals during which these sets of items were used (Zhulnikov 2009). However, they cannot be regarded as disposable, because some pieces have polished surfaces here and there. Thus they were kept safe for some time and a number of unknown actions were performed with them until the moment they were discarded.

Fragments of vessels with sculptures of human head on the rim and vessels decorated with a belt of waterfowl images around the rim (on both of which this paper focuses), are sometimes found at the same sites and in similar contexts with clay sculptures, and also come from Comb-Pitted Ware cultures. The best example is the set from Peski IV-a site, Karelia (Fig. 2), which was found in an area of $25 \mathrm{~m}^{2}$ inside a dwelling (Kashina 2007; Zhulnikov, Kashina 2010).

It is necessary to mention that the same clay paste was used for ordinary vessels, special ones and sculp- 

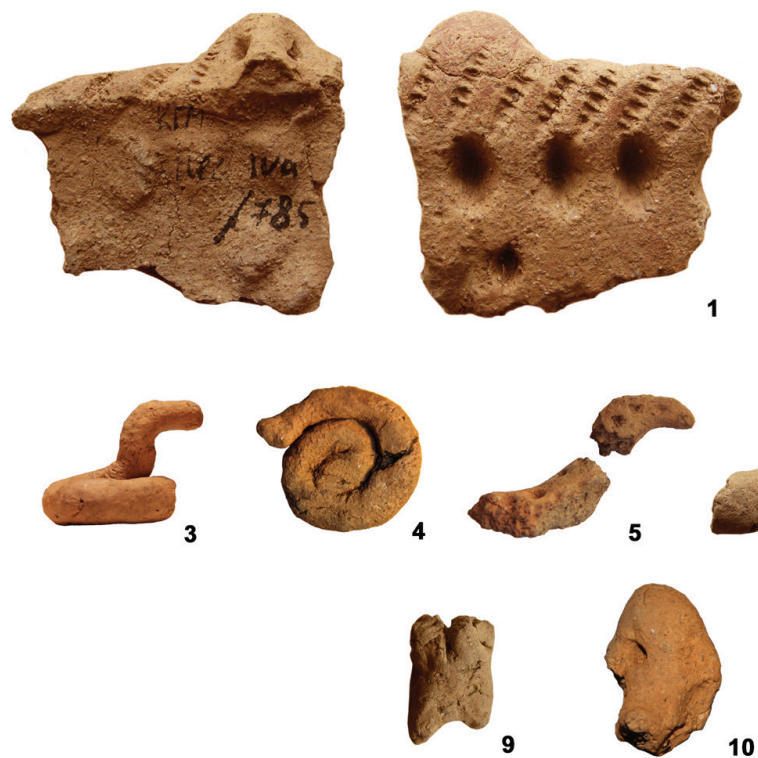

Fig. 2. Set of ceramic objects, Peski IV-a site, Republic of Karelia, Russia (photo: E. Kashina, A. Zhulnikov). 1 vessel fragment with human head; 2 vessel fragment with birds; 3-4 snake sculptures; 5-6 bird sculptures; 7-8 unknown sculpture fragments; 9-10 human sculpture fragments.

tures, so it can be supposed that sculptures and special vessels were made simultaneously with ordinary ones. Thus, there existed certain symbolic connections between sculptures and special vessels in rituals. The sets in question could represent a model of the universe and the presence of anthropomorphic ancestors in this context. They are believed to have played an important part in female spirituality and were probably needed to protect a particular dwelling, family members and especially children (Kashina 2009).

\section{Images and vessels: morphological groups}

The ceramic art connected with vessels can be divided into five groups:

(1) fragments of vessels decorated with a belt of waterfowl images around the rim;

(2) fragments of vessels decorated with images of humans and humans with birds;

(3) fragments of vessels with human head sculptures on the rim;

(4) fragments of vessels with full-figure sculpture/relief sculpture;

5 fragments of vessels with a zoomorphic head on the rim.

Group 1 consists of nearly 40 pieces (single sherds or partly preserved vessels), most of which are connected with the Baltic Comb and Finnish Comb-Pitted Ware (Pesonen 1996). Several finds have also
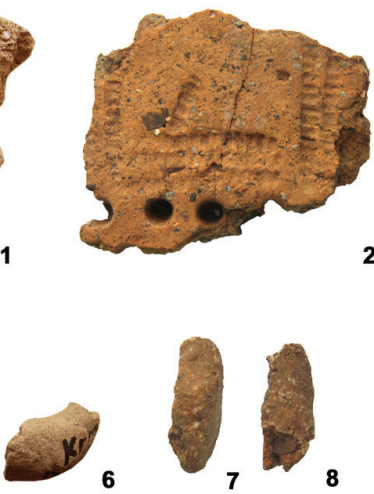

been made in the centre and north of European Russia. Before firing, images of swans or geese were made with comb stamps below the vessel rim, usually about $4 \times 6 \mathrm{~cm}$, and definitely representing birds swimming in a row to the left (more rarely) or to the right (Fig. 3).

Most vessels were reconstructed as large examples, 30$40 \mathrm{~cm}$ in diameter and height, with 15-24 birds depicted on them (Zhulnikov, Kashina 2010), but some could have been smaller (about $20 \mathrm{~cm}$ in diameter) (Schulz 2006). Several partly preserved vessels were found in dwellings; two have holes and even resin pieces, clear evidence of restoration. So far, no organic residue has been detected on the inner surfaces of any sherds, except one vessel fragment from the Joroinen Kanava site in Finland (ibid.).

Group 2 consists of seven images of humans below the vessel rim and another two vessels where a human is placed in a row of birds. All finds are single sherds or partly preserved vessels. Two pieces, socalled Porous Ware, found in Latvia and the Vologda district, date to the terminal phase of the Neolithic or the Early Bronze Age. Three pieces (Finland, Velikiy Novgorod district) are Late Comb Ware, four pieces (Lithuania, Republic of Belarus) are Corded Ware. Linear stamped or sometimes carved human figures measuring $6-10 \mathrm{~cm}$ are depicted en face with legs apart or bent at the knees, apparently dancing;

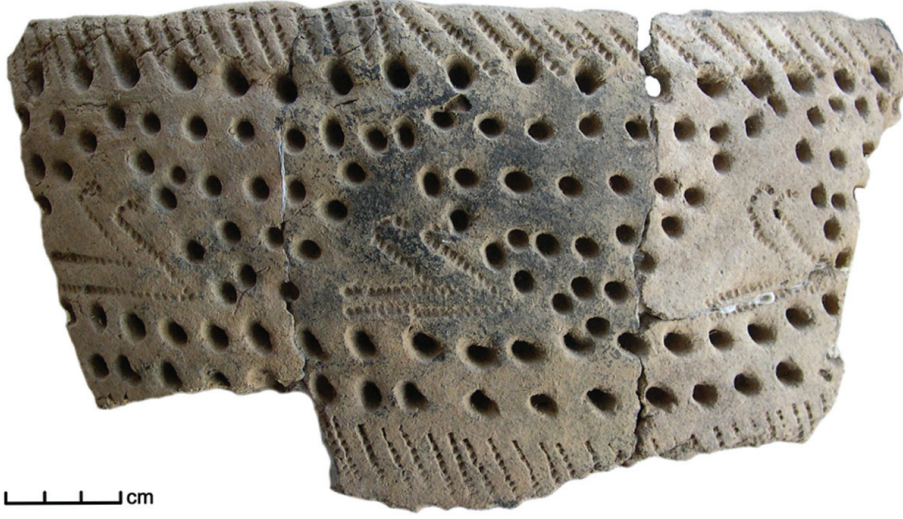

Fig. 3. Vessel fragment with bird images, Chornaya Guba IX, Republic of Karelia, Russia (photo: E. Kashina). 
sometimes the belt zone is marked with a horizontal line, and sometimes horns or a phallus appear ( $\mathrm{Ka}$ shina 2006). A vessel from Kolomtsy (Velikiy Novgorod district) (Fig. 4) was found buried (Peredolski 1905), so perhaps this bird/human/bird-human ornamentation was 'hidden' when the vessel was in use.

Group 3 consists of nine sherd finds from different sites distributed rather compactly to the east, from the Gulf of Finland of the Baltic Sea, depicting a human head attached to the rim, facing into the vessel. These heads fully correspond to the anthropomorphic sculptures, and are contemporaneous, but dispersed more locally. Their head decoration, when present, consists of two types, both made with a comb stamp: an inverted trident and a row of oblique imprints continued on the vessel rim. The rim head from the Peski IV-a site (see Fig. 2, 1, reverse side) was painted with red ochre. According to the reconstruction based on another find from Karelia a large vessel from Chornaya Guba IX site (Fig. 5) four heads were placed crosswise on one vessel.

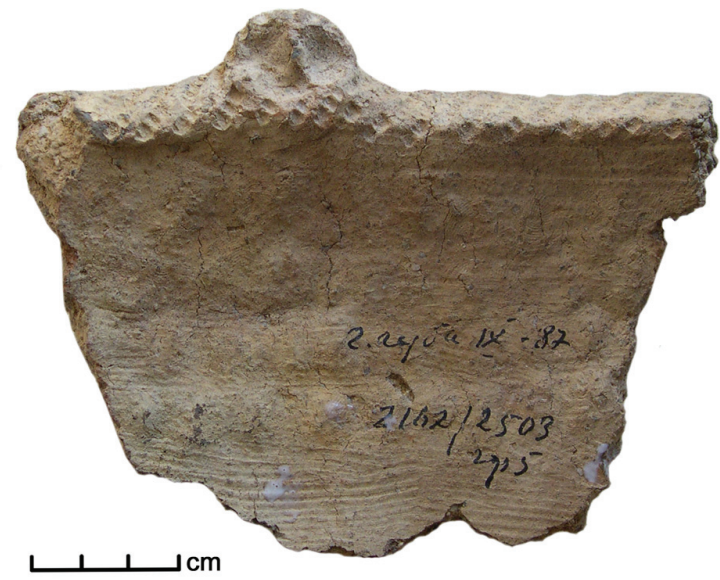

Fig. 5. Vessel fragment with a human head on the rim, Chornaya Guba IX, Republic of Karelia, Russia (photo: E. Kashina).

It is also necessary to mention that this large example (diameter $50 \mathrm{~cm}$, height $60 \mathrm{~cm}$ ) was restored with resin and stringing (Vitenkova 2002). According to Alexandr Zhulnikov, simple protrusions on vessel rims occurred in different regions of north eastern Europe from the Final Stone Age until the Early Iron Age and do not correspond directly to the abovementioned Group 3, which is distributed rather locally. Nevertheless, he argues that both Early and Late hunter-gatherers of the north eastern European forest zone shared quite similar worldview and beliefs, which is why rim protrusions, being obviously non-utilitarian details, appeared here and there during several epochs (Zhulnikov 2012).

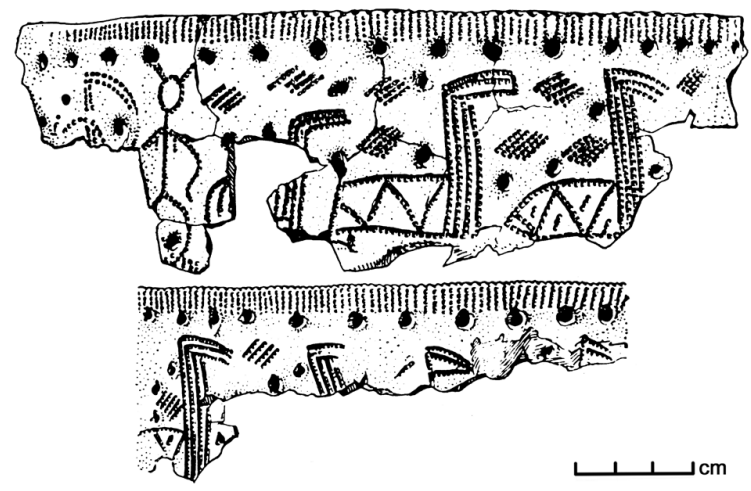

Fig. 4. Vessel fragment with human and bird images, Kolomtsy, Velikiy Novgorod district, Russia (after Peredolsky 1905).

Group 4 includes six pieces. Two sculptures attached to the vessel rim are Asbestos Ware (Karelia) and one to Late Pitted-Comb Ware (Central Russia). Two relief sculptures of full human figures (Lithuania and Central Russia) and one relief sculpture of a human head (Latvia) probably date to the Late Neolithic/ Early Bronze Age (Porous Ware). All images are situated immediately below the vessel rim. According to the reconstruction by Zhulnikov, two human figures found in a dwelling were placed opposite each other on one vessel, as if 'looking' inside the vessel, and some feathers were perhaps attached to their heads, because several pinholes were made in them (Fig. 6).

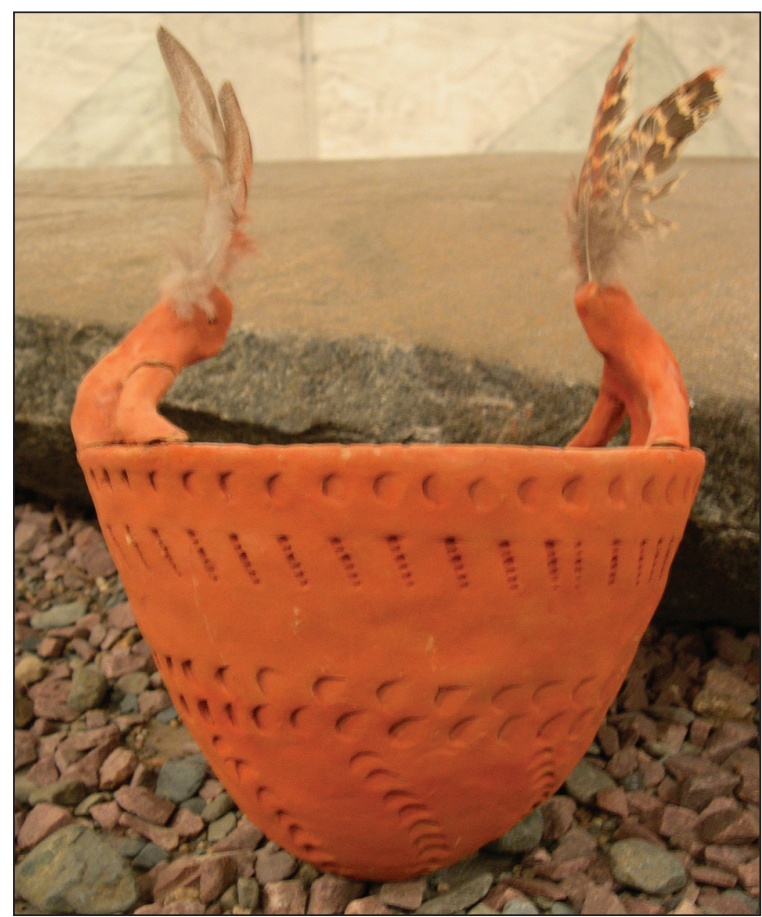

Fig. 6. Reconstruction (plaster) of a vessel with figurative sculptures found at Voinavolok $\mathrm{XXV}$ site, Republic of Karelia, Russia (photo: E. Kashina). 
The comparison of the human figures coloured with red ochre reveals a certain difference in details: 'blind'/pin-holed eyes, three/four pin-holes on the top of the head. Three relief sculptures of a human figure/head differ greatly from each other and were separated by long distances (Lithuania, Latvia and Nizhny Novgorod district), so they probably reflect convergent traditions. Two full-figure reliefs 'hug' the vessel with long outspread arms, their legs slightly apart. Both examples (Nizhny Novgorod district and Lithuania) date to approx. 3000 calBC or even later (Fig. 7).

Group 5 consists of four quite similarly modelled pieces: the head of an unknown mammal on a rim with a protruding muzzle and raised ears, facing away from the vessel. All finds are from the centre of European Russia and situated comparatively close to the forest-steppe border (the Volga and Oka River basin). All of them are from Eneolithic-Early Bronze Age ceramic traditions, probably dating to 30002500 calBC or even later. One vessel (Galankina Gora, Republic of Marij-El) was found in the fireplace area of a dwelling (Solov'iev 1987). Another fragment (Vladychinskaya-Beregovaya I site, Ryazan district) (Fig. 8) (Studzitskaya 1980) has a pinhole in the top of the head, probably for fastening a feather or something else. This unique type of vessel sculpture was probably influenced by some cultural impulse from the forest-steppe zone, but direct analogues remain unknown.

\section{Conclusions}

Ceramic sculpture and graphics on vessels provide abundant data for studying hunter-gatherers' ritual life, domestic beliefs, mythology, pottery making and pottery decoration. Several common traits unite these materials. Firstly, these are rare finds, made in settlement contexts, supposedly in a dwelling, or near a fireplace. They were obviously not connected with funeral rites, but only with hearth and home. Secondly, the position of the image on the vessel is always very similar, regardless of the region, ceramic traditions or period, i.e. close to the vessel edge. The sculpture is on the rim top; reliefs and graphics are on the upper surface adjoining the rim. Thirdly, these sets of sculptures and special vessels were handled with care for extended periods and definitely were not disposable items. Taking into consideration the fact that such ceramics were probably made by women, it can be inferred that the general symbolic meaning of all these special vessels could have been connected with female spirituality,
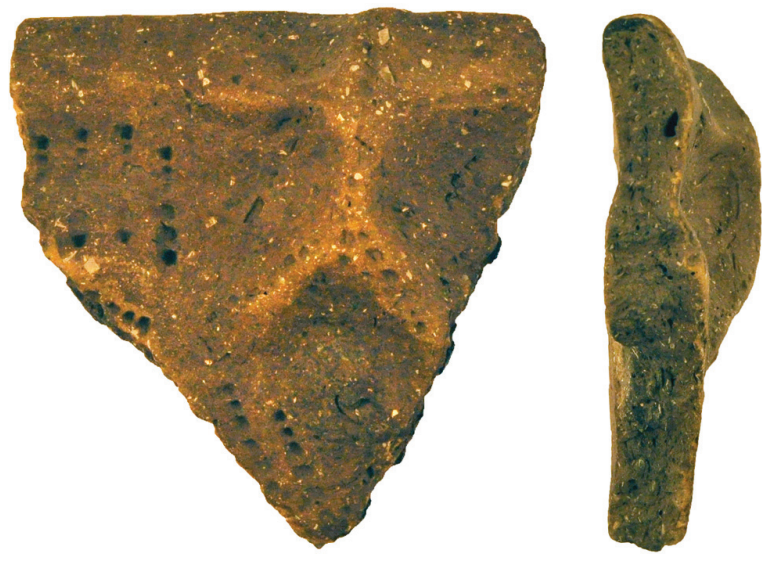

\section{$1 \quad 1 \quad 1 \quad \mathrm{~cm}$}

Fig. 7. Vessel fragment with a human figure in relief, Volosovo, Nizhniy Novgorod district, Russia (photo: E. Kashina).

rites performed inside the house, probably of an occasional character, and with the storage of some unknown content in such vessels, which unfortunately in most cases have left no residues on their inner surfaces.

The idea of the vessel edge as a 'liminal' zone which needs special protection against evil seems to be a universal, ecumenical notion, connected not only with ceramic vessels, but also with caves, female bosom, plaited hair, wounds, costume cuffs and belts etc., and widely discussed in the literature (see e.g., Moshinskaya 1976; Antonova 1984).

The special meaning of waterfowl images (which are also among the sculptural and graphic images on vessels) for north Eurasian prehistoric hunting societies has already been mentioned in a number

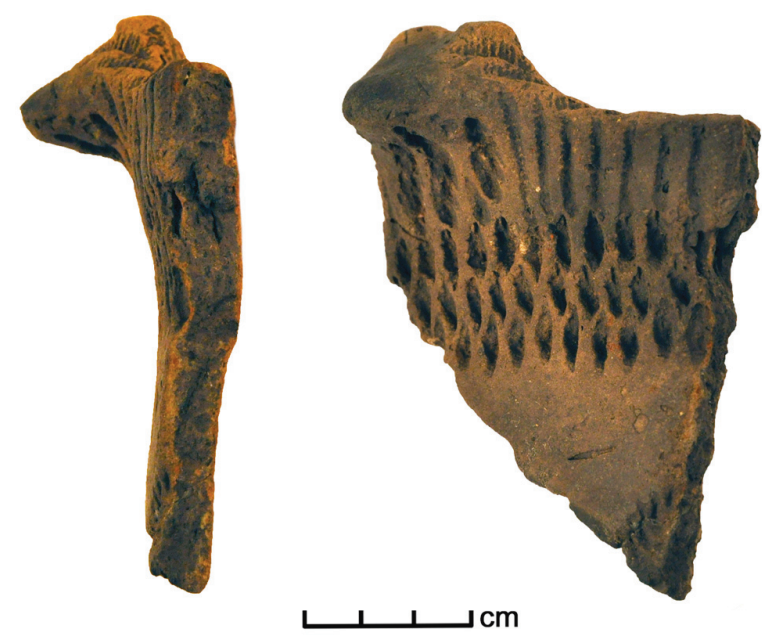

Fig. 8. Vessel fragment with zoomorphic relief, Vladychinskaya Beregovaya I, Ryazan district, Russia (photo: E. Kashina). 
of semantic/semiotic studies. Waterfowl played a notable role in cosmology and the cycle of life and death, and were strongly connected with such notions as the 'human soul' and 'childhood' (see e.g., Napol'skikh 1990; Zhulnikov 2009). A decorative belt of swimming swans or geese surrounding the vessel and probably also protecting its contents appears on some finds. The idea of a vessel as a symbol of the universe is also well known from archaeological and ethnological studies (see e.g., Antonova 1984; Kosarev 2008).

The volume of vessels in the eastern European forest zone Final Stone Age, is recognised generally as 20-50 litres. This fact, no matter whether it was for cooking or for storage, could mean the collective use of contents: big meals, big stocks of edible (or nonedible) stuff consumed or kept, obviously, by one family or kin group. Even moving a large vessel filled with something could require concerted action by, for example, two people.

Returning to chronology, the earliest images in our study, the so-called sets of sculpture, the interpretation of figurative sculptures as ancestors, accompanied by animals of three universal levels - birds (sky), mammals (ground) and snakes (underworld) have already been discussed (Kashina 2007). Evidently, the same ancestors were depicted as vessel guardians in the form of human figures or heads on the rims. Graphic and relief representations of human figures seem to be the latest, but could also be interpreted as vessel guardians. Depicted individually, not accompanied by birds, they probably reflect some changes in beliefs, perhaps influenced by heterogeneous groups which also settled the forest zone (Globular Amphorae, Corded Ware, Battle Axes, Fatyanovo), traces of which are sometimes visible in local material culture (Girininkas 2002).

The 'Neolithic decline' and the formation process of Bronze Age forest hunter-gatherer cultures are not clear enough. Seemingly, some traditions survived; for example, some rare finds of vessels decorated with birds in central and north-eastern European Russia are slightly reminiscent of Neolithic ones (Zhulnikov, Kashina 2010). Also, some vessel fragments with simple protrusions on the rims are known from the eastern European forest zone, probably an echo of Late Neolithic/Early Metal Period rim sculptures (Zhulnikov 2012). The appearance of the 'vessel-guardian' idea and also of clay sculpture production in the Eastern European forest zone definitely was a process that occurred independently of southern pastoral/agricultural traditions. It seems to have originated in south-eastern Finland, southern Karelia and northern European Russia between 5000 and 4000 calBC (Ivanischeva, Kashina 2015).

We are grateful to Prof. Mihael Budja for his kind invitation to publish our paper in this volume and also to Dr. Irina Vitenkova and Dr. Aleksey Tarasov (Institute of Linguistics, Literature and History, Karelian Research Centre of the Russian Academy of Sciences, Petrozavodsk) for their kind permission to use photographs of vessels excavated in Karelia in this paper.

\section{References}

Antonova E. 1984. Ocherki kul'tury drevnikh zemledeltsev Peredney I Sredney Azii. Opyt reconstruktsii mirovospriyatiya. (Essays on ancient agricultural societies of West and Middle Asia. An attempt of worldview reconstruction). Nauka. Moscow. (in Russian)

Bahder 0., Kraynov D. and Kosarev M. (eds.) 1987. Epokha Bronzy Lesnoy Polosy SSSR. (The Bronze Epoch of the forest zone of the USSR). Nauka. Moscow. (in Russian)

Girininkas A. 2002. Migraciniai procesai Rytų Pabaltyje vèlyvajame neolite: virvelinès keramikos kultūra. (Migra- tory processes in the East Baltic in the Late Neolithic: Corded Ware culture). Lietuvos Archeologija 23: 73-92.

Ivanischeva M., Kashina E. 2015. Nabory neoliticheskoy glinyanoy skul'ptury na pamyatnikakh Yuzhnogo Prionezh'ya. (Sets of Neolithic clay sculpture on the Southern shore of the Onega Lake). Twerskoy Arkheologicheskiy Sbornik 10(1): 474-480. (in Russian)

Kashina E. 2006. Izobrazheniya cheloveka na neo-eneoliticheskoy keramike lesnoy zony Vostochnoy Yevropy (Human images on the Neolithic-Eneolithic ceramics of the Eastern European forest zone). In A. Martynov (ed.), 
Pervobytnaya i srednevekovaya istoriya i kul'tura Yevropeyskogo Severa: problemy izucheniya $i$ nauchnoy rekonstruktsii. Solty. Arkhangelsk: 92-97. (in Russian)

2007. Nabory lepnykh zoomorfnykh skul'ptur v neoliteeneolite lesnoy zony Vostochnoy Yevropy i Finlyandii (Sets of modeled zoomorphic sculptures in the Neolithic-Eneolithic of the forest zone of Eastern Europe and Finland). In S. Arutyunov (ed.), Mif, obryad i ritual'niy predmet $v$ drevnosti. Magellan. YekaterinburgSurgut: 125-135. (in Russian)

2009. Ceramic Anthropomorphic Sculptures of the East European Forest Zone. In P. Jordan, M. Zvelebil (eds.), Use of Ceramics by Old-World Hunter-Gatherers: Form, Function and Symbolic Meaning. Left Coast Press. Wallnut Creek: 281-297.

Kosarev M. 2008. Osnovy yazycheskogo miroponimaniya: po sibirskim arkheologo-etnographicheskim materialam. (Pagan worldview basics: due to Siberian archaeological and ethnographical data). Slava. Moscow. (in Russian)

Loze I. B. 2005. Small anthropomorphic figurines in clay at Gipka Neolithic settlements. Documenta Praehistorica 32: 155-165.

Moshinskaya V. 1976. Drevnyaya skulpture Urala I Zapadnoy Sibiri. (Prehistoric sculpture of Urals and Western Siberia). Nauka. Moscow. (in Russian)

Napol'skikh V. 1990. Mif o vozniknovenii Zemli v praural'skoy kosmogonii (Myth of the Earth birth in pra-urals cosmogony). Sovetskaya Ethnografija 1: 64-74. (in Russian)

Núñez M. 1986. Clay figurines from the Åland Islands and mainland Finland. Fennoscandia Archaeologica 5(3): $17-34$.

Oshibkina S. V. (ed.) 1996. Neolit Severnoi Yevrazii. (North Eurasian Neolithic Age). Nauka. Moscow. (in Russian)

Peredolski W. 1905. Eine bildiche Darstellung des Menschen auf einen neolithischen Tongefass. Archiv für Anthropologie 3(4): 289-294.

Pesonen P. 1996. Rääkkylän joutsenet ja muita kampakeramiikan linnunkuvia. (Swans from Rääkkylä and other bird images on Comb-Pitted Ware). Kentältä poimittua 3. Kirjotelmia arkeologian alalta. Museoviraston arkeologian osaston julkaisuja. 6. Museovirasto. Helsinki: 5-14.
Piezonka H., Kostyleva E., Zhilin M., Dobrovolskaya M. and Terberger T. 2013. Flesh or fish? First results of archaeometric research of prehistoric burials from Sakhtysh IIa, Upper Volga region, Russia. Documenta Praehistorica 40: 57-73. doi: 10.4312/dp.40.6

Schultz E.-L. 2006. Die Vögel von Joroinen Kanava. In M. Suhonen (ed.), Arkeologian lumoa synkkyyteen: Artikkeleita Christian Carpelanin juhlapäiväksi (Lighting the darkness - the attraction of archaeology: Papers in honour of Christian Carpelan). Helsingin yliopisto. Helsinki: 112-121.

Solov'iev B. 1987. Noviye raskopki poseleniya Galankina Gora. (New excavation at Galankina Gora settlement). $A r$ kheologiya i Etnografija Mariyskogo Kraya, Drevnosti Srednego Povolzhya 13: 79-101. (in Russian)

Studzitskaya S. 1980. Figurniye nalepy na sosudakh so stoyanok volosovskoy kultury. (Figural protrusions on vessels from Volosovo culture sites.) Trudy Gosudarstvennogo istoricheskogo muzeya 51: 25-30. (in Russian)

Tsetlin Y. 1998. Kulturniye kontakty v drevnosti: obschaya sistematika I otrazheniye ikh v kulturnykh traditsiyakh goncharov. (Prehistoric cultural connections: general classification and reflection in cultural traditions of potters.) Tverskoy Arkheologicheskiy Sbornik 3: 50-63. (in Russian)

Vitenkova I. 2002. Pamyatniki pozdnego neolita na territorii Karelii. (Late Neolithic sites in Karelia). Karelian Scientific Centre. Petrozavodsk. (in Russian)

Zhulnikov A. 2006. Asbest kak pokazatel' svyazey drevnego naseleniya Karelii. (Asbestos as the marker of connections between prehistoric societies of Karelia). Tverskoy Arkheologicheskiy Sbornik 6(1): 330-333. (in Russian)

2009. Äänisen kalliopiirroksia (Lake Onega petroglyphs). Kustannusyhtiö ILIAS oy. Pohjois-Karjalan museo. Joensuu.

2012. Skul'pturniye izobrazheniya na keramicheskoy posude v kontekste svyazey drevnego naseleniya Vostochnoy Yevropy I Zaural'ya. (Sculptures on ceramic vessels in the context of Eastern European and TransUrals prehistoric societies connections.) Uchonye Zapiski Petrozavodskogo Universiteta. Istoriya 1: 1217. (in Russian)

Zhulnikov A., Kashina E. 2010. Obraz ptitsy v iskusstve neolita-eneolita lesnoy zony Vostochnoy Yevropy (The bird image in the Neolithic-Eneolithic art of the Eastern European forest zone). Rossiyskaya Arkheologiya 2: 517. (in Russian) 
